\title{
PLANAR ASYMMETRIC DUAL DIODE FOR MILLIMETRE WAVE DETECTION AND POWER MEASUREMENT
}

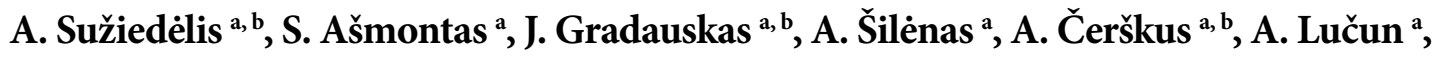 \\ Č. Paškevič ${ }^{a}, M$. Anbinderis ${ }^{a, b}$, and O. Žalys ${ }^{a}$ \\ ${ }^{a}$ Center for Physical Sciences and Technology, Sauletekio 3, 10257 Vilnius, Lithuania \\ ${ }^{\mathrm{b}}$ Vilnius Gediminas Technical University, Sauletekio 11, 10223 Vilnius, Lithuania \\ Email: algirdas.suziedelis@ftmc.lt
}

Received 9 June 2017; revised 12 September 2017; accepted 20 September 2017

\begin{abstract}
The design of a simple cost-effective planar semiconductor microwave diode is proposed. The operation is based on hot carrier phenomena and rectification of microwave currents flowing through the structure composed of two diodes connected in series and having different active region areas. A simplified technological process and the use of simplex semiconductor material result in the reduction of both the time and the cost of fabrication of a dual microwave diode. By choosing an appropriate GaAs substrate, two types of microwave diodes were produced simultaneously: one almost demonstrating the ohmic behaviour and the other two having the asymmetrical Schottky-like $I-V$ characteristic. The Schottky-like planar diodes exhibited a higher responsivity to millimetre range microwave radiation and a faster response to pulsed (down to a nanosecond scale) excitation, but the ohmic ones demonstrated better noise properties.
\end{abstract}

Keywords: millimetre wave power measurement, ohmic contacts, Schottky junctions

PACS: 68.35.bg, 84.40.-x, 07.57.Kp

\section{Introduction}

Increased interest in the electromagnetic radiation of a millimetre wavelength range is generally stimulated by its possible applications in modern fields such as imaging of concealed objects [1, 2], material homogeneity inspection [3], adaptive

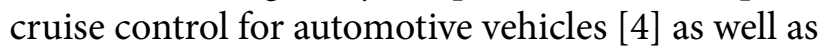
for future broadband cellular communication networks [5]. Successful detectors and power meters in this range require sensitive, reliable, fast and costeffective microwave (MW) diodes. Definite advantages are inherent to widely used MW Schottky diodes [6]. However, a lot of other diodes, e.g. camel [7], planar-doped barrier [8], heterojunction [9, 10], hot carrier [11-13], all operating on the basis of the major carrier phenomena in semiconductors are proposed as well. All these majority-carrier devices, except the Schottky diodes, belong to the class of bulk-barrier diodes. The development of Schottky diodes brought scientists and engineers to the camel diodes when in 1979 Shannon proposed to replace the metal-semiconductor barrier with

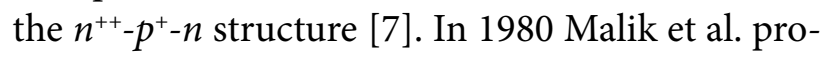
posed to insert layers of an intrinsic semiconductor between the oppositely doped layers, and the camel diode structure was transformed to the $n^{+}-i-p^{+}-i-n^{+}$ planar-doped barrier structure [8]. In 1980 Lechner et al. reported a heterojunction diode that detected microwave radiation on the GaAs/GaAlAs heterojunction barrier. Later on a sensitive heterojunction diode was used for the detection of electromagnetic radiation in a wide frequency range from microwaves to infrared frequency [10]. Formerly an original microwave diode was proposed by Harrison and Zucker [11] the operation of which was based on hot carrier phenomena in a semiconductor. Planar versions of the hot carrier diodes were elaborated where the $n^{+}-n$ silicon homojunction [12] and the modulation-doped GaAs/AlGaAs two-dimensional electron gas structure [13] was used for the MW detection. The aforementioned 
MW diodes are mainly fabricated of more or less complex epitaxial semiconductor structures, in most cases MBE grown.

In this paper we suggest a novel dual microwave diode distinguished firstly for its design simplicity, since only the heavily doped $n^{+}$-GaAs and $p^{+}$GaAs semiconductor substrates with a smoothly polished surface were chosen as basic materials for the diode fabrication. The number of fabrication process steps is minimized if compared to the production of the MW Schottky diode or the heterojunction diode [10]. The voltage signal induced across the terminals of diodes exposed to the millimetre wave radiation of the $\mathrm{K}_{\mathrm{a}}$-frequency range is studied in this paper. The diodes operated in a direct detection zero-biased mode making simple their use in MW power measurement devices.

\section{Samples and experiment}

Three types of heavily doped polished GaAs substrates, $n^{++}$-GaAs having donor density $4 \times 10^{18} \mathrm{~cm}^{-3}, n^{+}$-GaAs, doped to $4 \times 10^{17} \mathrm{~cm}^{-3}$, and $p^{++}$-GaAs having $4 \times 10^{18} \mathrm{~cm}^{-3}$ acceptor density, were taken as the basic material for the fabrication of MW diodes. Both contacts (a small area on the left and a large area on the right, see Fig. 1) were made in one step of thermal evaporation of $\mathrm{Ge} / \mathrm{Ni} / \mathrm{Au}$ metals followed by rapid annealing at $430{ }^{\circ} \mathrm{C}$ temperature in hydrogen atmosphere. Different areas of the contacts make the planar diode structure asymmetric in the sense of an active region. Moreover, such a MW diode can be
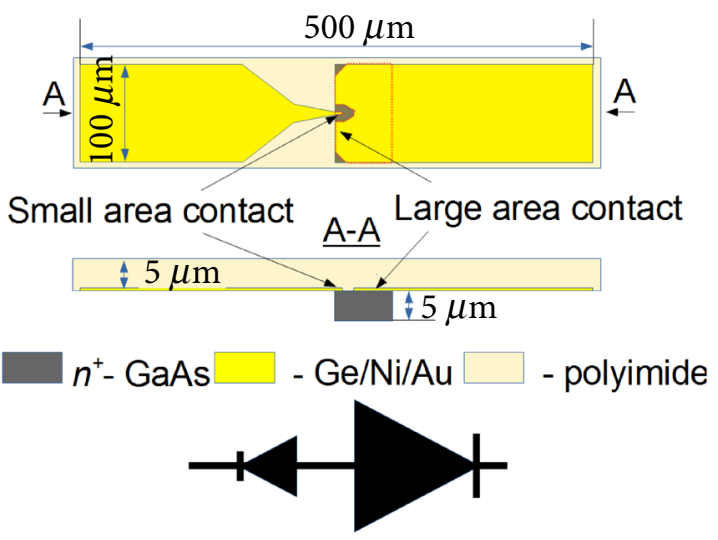

Fig. 1. Schematic view of the planar dual semiconductor MW diode. treated as a couple of different diodes connected in series, as it is schematically depicted in Fig. 1. After the annealing, contact resistivities were in the range of $(1-50) \times 10^{-6} \Omega \mathrm{cm}^{2}$ for the diodes fabricated on the base of the $n^{++}$-GaAs substrate, and about (3-10) $\times 10^{-5} \Omega \mathrm{cm}^{2}$ for those fabricated from the $n^{+}$-GaAs substrate. The contact resistivity of the $p^{++}$-GaAs-based diodes was much higher, indicating a typical Schottky contact behaviour of both, large and small, diodes. The diode structures were transferred onto an elastic dielectric polyimide film in the same manner used for heterojunction diode fabrication [10]. Scattering of the contact resistivity values can be explained by a non-homogeneous recrystallization process during $\mathrm{Ge} / \mathrm{Ni} / \mathrm{Au}$ metal contact alloying into GaAs. Surface morphology of the semiconductor after alloying becomes non-uniform, revealing $\mathrm{Ge}$ and $\mathrm{Ni}$ rich clusters having dimensions from half to few micrometres [14]. These sizes are comparable to contact sizes, therefore, the electrical resistance of dual microwave diodes gains different values on the same GaAs substrate.

In the case of $n^{++}$- and $n^{+}$-GaAs substrates the electrical resistance of the fabricated dual microwave diodes was relatively low, between tens and hundreds of ohms. However, the $I-V$ characteristic of the diodes was either typical of the Schottky contact or almost an ohmic one with a very small asymmetry (see Fig. 2). Further, in this paper these diodes are labelled as LS and LO, and we call them low resistivity Schottky diodes and ohmic diodes, respectively. Accordingly, high resistance diodes made on the $p^{++}$-GaAs substrate were named as HS diodes.

Using appropriate probe stations, measurements of DC current-voltage and high frequency voltage-power characteristics were performed directly on separate diodes uncut out of the whole diode array held by the polyimide film. DC measurements were performed using a Suss MicroTec EP6 probe station, while microwave measurements were done on a Cascade Microtech high frequency probe station. Measurements of the dependence of the output signal on frequency as well as the response-time of the investigation diode under pulsed excitation were performed by embedding separate microwave diodes into a waveguide head. A separate diode was mounted into a microstrip line where a quasi-transverse EM wave propagates. 
A fin-line adapter connects the microstrip line with an embedded diode to a rectangular waveguide where a $\mathrm{H}_{10}$ mode propagates. As a source of MW radiation, a traveling-wave tube generator operating in the $\mathrm{K}_{\mathrm{a}}$ frequency range and working in either a CW rectangular meander-modulated or a single pulse-modulated mode was used. All measurements were carried out at room temperature.

\section{Results and discussion}

The $I-V$ characteristics of the investigated MW diodes are presented in Fig. 2. The ohmic nature of dependences was inherent in most diodes fabricated on the base of the $n^{++}-\mathrm{GaAs}$ substrate: $80 \%$ of them were LO, and $20 \%$ were LS. As for the ones on the $n^{+}$-GaAs substrate, $70 \%$ of the diodes had ohmic characteristics (LO), and the rest $30 \%$ diodes were LS. The forward direction of the ohmic $I-V$ characteristic was assumed with the positive potential applied to the large area contact (see Fig. 1). In the case of Schottky-like characteristics, the forward current flowed when the positive potential was applied to the small area contact. As Fig. 2 shows, HS diodes revealed distinct $I-V$ characteristics, extremely non-linear and asymmetric. Also a big difference in the zerobias electrical resistance of the diodes has been identified: tens of ohms, hundreds of ohms and tens of megaohms for the LO, LS, and HS diodes, respectively.

Asymmetry of the $I-V$ characteristics of the diodes can be related to their prospective respon-

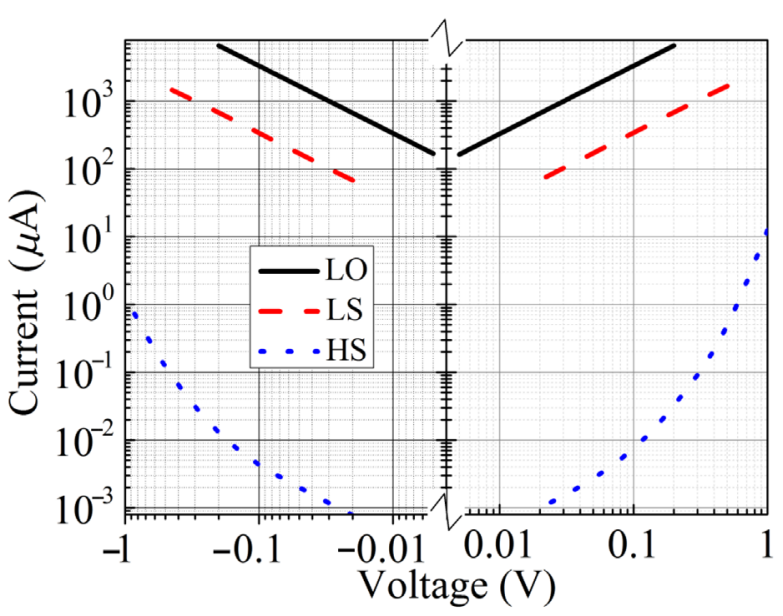

Fig. 2. The $I-V$ characteristics of the LO, LS and HS MW diodes (in a log/log scale). sivity to the MW radiation. The voltage responsivity $R_{v}$ of the MW diode formed on the base of the small area $n-n^{+}$junction (point contact diode) depends on the asymmetry of the $I-V$ characteristic calculated according to the formula [12]

$$
\text { Asymmetry }=R_{v}=\frac{R_{\mathrm{r}}-R_{\mathrm{f}}}{2 U},
$$

where $R_{\mathrm{r}}$ and $R_{\mathrm{f}}$ denote the electrical resistance of the diode under the reverse and the forward bias voltage $U$, respectively. It is worth to note that the prospective responsivity calculated according to Eq. (1) is with respect to the all absorbed MW power in a waveguide.

Absolute values of the $I-V$ characteristics asymmetry versus the applied voltage are presented in Fig. 3. Because the asymmetry of $I-V$ characteristics forecasts the responsivity of the MW diodes, the unit of the asymmetry is presented as volt per watt in Fig. 3. Naturally, Schottky-like characteristics demonstrate higher asymmetry values. A stronger asymmetry presumes the expectancy of higher detection properties of the MW diodes. Really, the voltage-power characteristics of the diodes measured at $f=28 \mathrm{GHz}$ frequency support this consideration (see Fig. 4). A huge difference between the prospective and experimental responsivity of the HS diode can be explained by a small portion of the MW power that absorbs the diode due to the high electrical resistance of

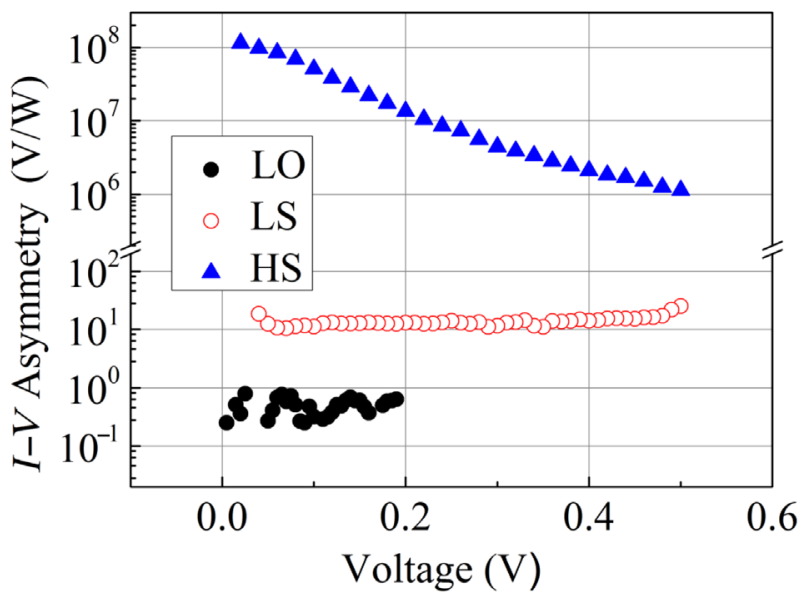

Fig. 3. Dependences of the asymmetry of $I-V$ characteristics of LO (solid dots), LS (open dots) and HS (triangles) diodes on the bias voltage calculated using Eq. (1). 


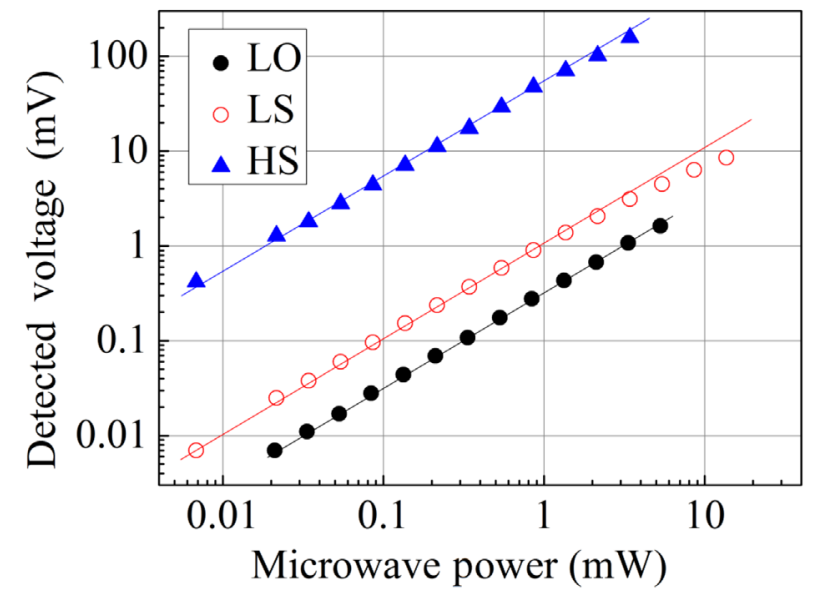

Fig. 4. The detected voltage versus the incident MW power of $f=28 \mathrm{GHz}$ frequency. The lines are guides representing linear dependence.

the HS diode. In the low power range, all three types of the diodes show linear dependences while at higher power levels the voltage-power characteristics of the LS and HS diodes start being sublinear. This deviation from linearity can be explained by microwave electric field-induced heating of a semiconductor crystal lattice occurring under the conditions of $\mathrm{CW}$ radiation. This presumption is also sustained by the change of the detected voltage magnitude with time at high level pulsed MW radiation (see below, Fig. 7). Still, the voltage-power characteristic of LO keeps linearity in a wider range of the MW power. In the case of electron heating by a strong electric field in the $n$-GaAs structure with different area Ohmic contacts the increase of detected voltage was observed, and it was explained by the rise of electron energy relaxation time [14-16] and electron diffusion coefficient values [17] with the increase of electric field strength.

The polarity of the voltage $U_{\mathrm{d}}$ detected across the diodes corresponds to the $I-V$ asymmetry sign. For example, a positive potential is induced on the small area contact of the LO diode. In this case $U_{\mathrm{d}}$ results from the hot electron EMF arising across the planar diode structure having ohmic contacts of different areas. On the other hand, LS diodes demonstrate the opposite polarity of $U_{\mathrm{d}}$. But the polarity of the voltage signal induced across HS diodes is the same as that across LO diodes, since the former diodes are fabricated on the base of the $p$-type substrate.
The frequency dependences of the voltage responsivity of MW diodes measured on a high frequency probe station under the conditions of $\mathrm{CW}$ radiation are presented in Fig. 5. The absolute value of voltage responsivity rises with the increase of semiconductor substrate resistivity (see graphs of LO and LS diodes). And a particularly high responsivity is noted for HS diodes, because the responsivity of Schottky diodes as a rule exceeds that of diodes operating on the basis of hot electron phenomena. Flat frequency dependence was inherent in all the investigated MW diodes in up to $34 \mathrm{GHz}$ frequency. Such weak dependence is typical of noninertial carrier heating phenomena under microwave electric field, what was observed in the case of LO diodes. What concerns the Schottky-like diodes LS and, especially, HS, their responsivity versus frequency dependences should be expressed stronger. Therefore, more detailed investigations of detection properties of Schottky-like diodes with respect to frequency would be performed in the future.

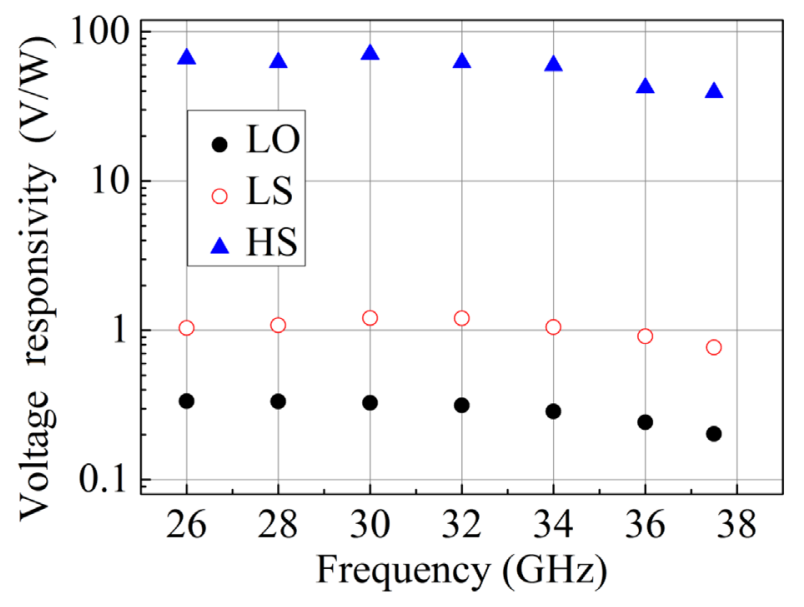

Fig. 5. Spectral distribution of the absolute value of voltage responsivity of the MW diodes measured by means of a high frequency probe station.

To compare frequency properties of the diodes, when they are measured using a high frequency probe station and in a waveguide, the LO and LS diodes were mounted on a waveguide head. The measured frequency dependences of voltage responsivity are presented in Fig. 6. Now voltage responsivity values are seen to be more than two times higher as compared to the probe station measurements. As Fig. 6 shows, the waveguide-mounted diodes do not demonstrate any obvious responsivity decrease 


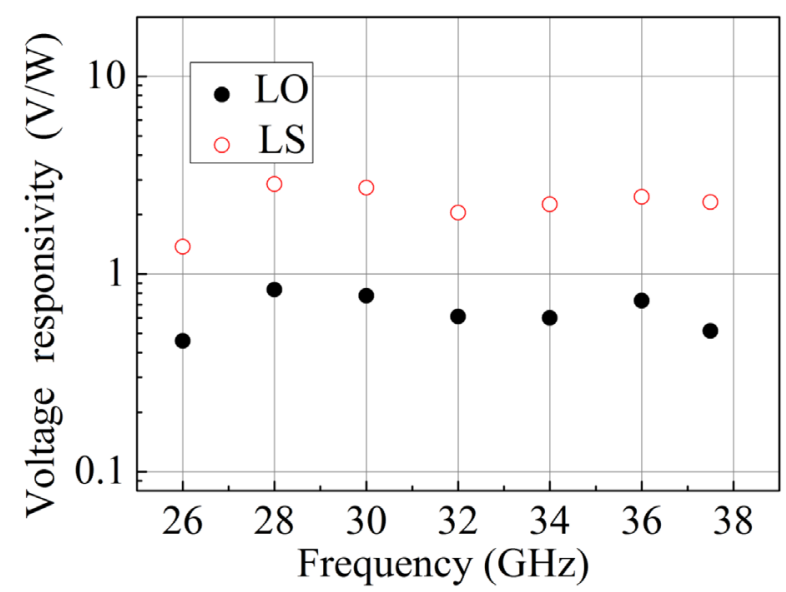

Fig. 6. Spectral distribution of the absolute value of voltage responsivity of the MW diodes embedded in a waveguide.

at frequencies above $34 \mathrm{GHz}$. However, the frequency dependences of the microwave diodes in the waveguide are more non-monotonic in comparison with probe station measurements due to the dependence of reflectance of the MW signal in the waveguide on frequency. This statement is supported by voltage standing wave ratio (VSWR) measurements in the $\mathrm{K}_{\mathrm{a}}$ frequency range. The value of the VSWR changed non-monotonically from 5.5 to 3.0 in this frequency range. The minimum value of the VSWR at 28 and $37 \mathrm{GHz}$ frequency corresponded to the maximums of voltage sensitivity of the LO and LS diodes at these frequencies.

Low values of the electrical resistance of $\mathrm{LO}$ and LS diodes along with their low capacitance values lying in the picofarad range open the possibility to use these diodes for fast detection of short-duration MW pulses. Figure 7 depicts the reaction of the LO diode to the rectangular MW pulse. The MW radiation was modulated into rectangular pulses of $1.5 \mu$ s duration with steep $10 \mathrm{~ns}$-long fronts at $100 \mathrm{~Hz}$ repetition rate. In the figure, the generator pulse (not to a voltage scale) and the detected voltage pulse are separated in the vertical direction for better visibility. The voltage detected across the LO diode grew exponentially with two characteristic time constants: one of the order of tens of nanoseconds and another in a microseconds time scale. Fast rise is attributed to electron heating phenomena in the microwave electric field, while the longer time constant is determined by crystal lattice heating. A similar two-process relaxation was observed after the end of the MW pulse. In the case of LS, a slow fall of the voltage magnitude under the action of the MW pulse as well as a slow relaxation after the pulse is gone can be attributed to crystal lattice heating (and later cooling) and surface charge relaxation phenomena in the Schottky junction. We relate the fast peaks at the start and end of the detected voltage pulse with the hot carrier photocapacitive effect in the Schottky junction of the LS diodes [18].

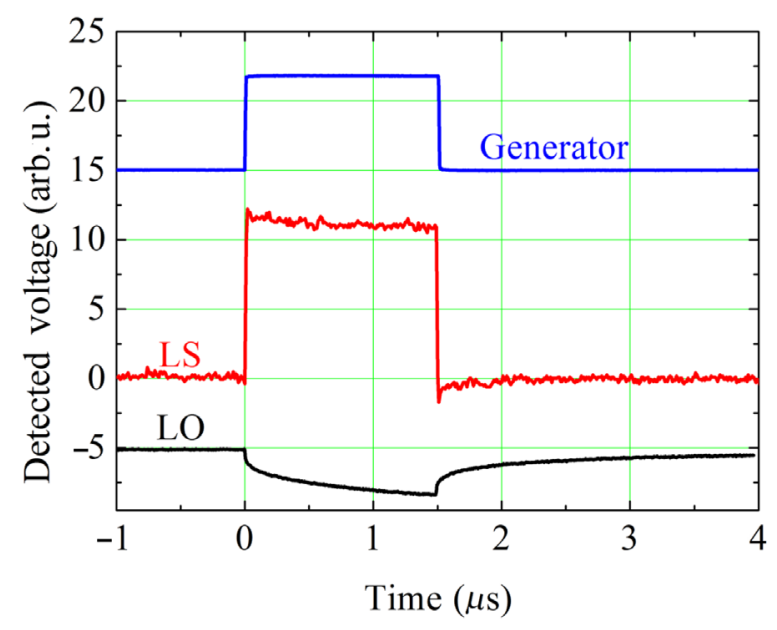

Fig. 7. Time dependences of voltage pulses across the diodes placed in a waveguide.

The voltage responsivity of the dual MW diodes LS is approximately three times higher than that of LO. Nevertheless, the latter reveal better noise properties as compared to those of the diodes containing the Schottky junction (see Fig. 7): the MW diodes operating on the basis of hot carrier phenomena are about twenty times less noisy than the ones with Schottky junctions.

\section{Conclusions}

Two types of novel planar semiconductor diodes as detectors of millimetre waves have been developed and investigated. Lower responsivity diodes demonstrated a good linearity of the voltage-power characteristic in a wide microwave power range; this feature makes the diodes suitable for microwave power measurements. Higher responsivity was achieved by means of choosing the appropriate substrate material depending on the conductivity type and doping level. A simple design and minimized steps of the fabrication process of the planar microwave planar diode as well as operation based 
on classical heating and current rectification phenomena make it attractive for application in both continuous wave and pulsed microwave detection in a millimetre frequency range.

\section{Acknowledgements}

This work was in part supported by the Research Council of Lithuania (Grant No. LAT-03/2016) in the frame of the National Science Program "Towards Future Technologies". The authors are thankful to Angelè Steikūnienè and Gytis Steikūnas for the sample preparation.

\section{References}

[1] P.F. Goldsmith, C.-T. Hsieh, G.R. Hunguenin, and J. Kapitzky, Focal plane imaging systems for millimetre wavelengths, IEEE Trans. Microw. Theory Tech. 41(10), 1664-1675 (1993), https:// doi.org/10.1109/22.247910

[2] S. Oka, H. Togo, N. Kukutsu, and T. Nagatsuma, Latest trends in millimeter-wave imaging technology, Prog. Electromagn. Res. Lett. 1, 197-204 (2008), https://doi.org/10.2528/PIERL07120604

[3] Ž. Kancleris, A. Laurinavičius, and T. Anbinderis, Sensitivity of homogeneity mapping of semiconductor wafer using millimetre waves, Int. J. Infrared Millimeter Waves 25(11), 1633-1644 (2004), https://doi.org/10.1023 B:IJIM.0000047453.30952.79

[4] S. Tokoro, K. Kurada, A. Kawakubo, K. Fujita, and H. Fujinami, Electronically scanned millimetre-wave radar for pre-crash safety and adaptive cruise control system, in: IEEE IV2003 Intelligent Vehicles Symposium. Proceedings (IEEE, Columbus, OH, USA, 2003) pp. 304309, https://doi.org/10.1109/IVS.2003.1212927

[5] T.S. Rappaport, S. Sun, R. Mayzus, H. Zhao, Y. Azar, K. Wang, G.N. Wong, J.K. Schulz, M. Samimi, and F. Gutierrez, Millimeter wave mobile communications for $5 \mathrm{G}$ cellular: It will work! IEEE Access 1, 335-348 (2013), https:// doi.org/10.1109/ACCESS.2013.2260813

[6] P.H. Siegel, Terahertz technology, IEEE Trans. Microw. Theory Tech. 50, 910-928 (2002), https://doi.org/10.1109/22.989974
[7] J.M. Shannon, A majority-carrier camel diode, Appl. Phys. Lett. 35(1), 63-65 (1979), https:// doi.org/10.1063/1.90931

[8] R.J. Malik, T.R. AuCoin, R.L. Ross, K. Board, C.E.C. Wood, and L.F. Eastman, Planar-doped barriers in GaAs by molecular beam epitaxy, Electron. Lett. 16(22), 836-838 (1980), https:// doi.org/10.1049/el:19800594

[9] A. Lechner, M. Kneidinger, and R. Kuch, Planar $n$-GaAs/N-GaAlAs microwave diodes, Electron Lett. 16(1), 1-2 (1980), https://doi.org/10.1049/ el:19800001

[10]J. Gradauskas, A. Sužiedèlis, S. Ašmontas, E. Širmulis, V. Kazlauskaitè, A. Lučun, and M. Vingelis, Sensitive planar semiconductor detector from microwave to infrared applications, IEEE Sens. J. 10(3), 662-667 (2010), https://doi. org/10.1109/JSEN.2009.2038654

[11]R.I. Harrison and J. Zucker, Hot-carrier microwave detector, Proc. IEEE 54(4), 588-595 (1966), https://doi.org/10.1109/PROC.1966.4778

[12]S. Ašmontas and A. Sužiedèlis, New microwave detector, Int. J. Infrared Millimeter Waves 15(3), 525-538 (1994), https://doi.org/10.1007/ BF02096235

[13]D. Seliuta, E. Širmulis, V. Tamošiūnas, S. Balakauskas, S. Ašmontas, A. Sužiedèlis, J. Gradauskas, G. Valušis, P.D. Steenson, W.-H. Chow, P. Harrison, A. Lisauskas, H.G. Roskos, and K. Köhler, Detection of terahertz/sub-terahertz radiation by asymmetrically-shaped 2DEG layers, Electron. Lett. 40(10), 631-632 (2004), https://doi. org/10.1049/el:20040412

[14]M. Heiblum, M.I. Nathan, and C.A. Chang, Characteristics of AuGeNi ohmic contacts to GaAs, Solid State Electron. 25(3), 185-195 (1982), https://doi.org/10.1016/0038-1101(82)90106-X

[15]S. Ašmontas and A. Sužiedèlis, Electric properties of small area GaAs $n^{+}$junction, Lith. J. Phys. 33(1), 45-51 (1993).

[16]K. Ashida, M. Inoue, J. Shirafuji, and Y. Inuishi, Energy relaxation effect of hot electrons in GaAs, J. Phys. Soc. Jpn. 37(2), 408-414 (1974), https://doi.org/10.1143/JPSJ.37.408

[17]J. Vaitkus, E. Starikov, L. Subačius, and K. Jarašiūnas, Field dependences of light self-diffraction 
efficiency and hot carrier diffusion coefficient in gallium arsenide and silicon, Lith. J. Phys. 30(3), 336-351 (1990).

[18]S. Ašmontas, J. Gradauskas, A. Sužiedèlis, E. Širmulis, and A. Urbelis, Hot carrier photocapaci- tive effect, Proc. SPIE 5946, 594619 1-6 (2004),

https://doi.org/10.1117/12.639324

\title{
PLANARINIS ASIMETRINIS DVIGUBAS DIODAS MILIMETRINIŲ BANGŲ DETEKCIJAI IR GALIOS MATAVIMUI
}

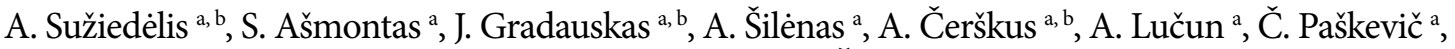 \\ M. Anbinderis ${ }^{a, b}$, O. Žalys ${ }^{a}$ \\ a Fiziniu ir technologijos mokslu centras, Vilnius, Lietuva \\ ${ }^{\mathrm{b}}$ Vilniaus Gedimino technikos universitetas, Vilnius, Lietuva
}

\section{Santrauka}

Straipsnyje pateikiama paprasta rentabili planarinio mikrobangų diodo konstrukcija. Diodo veikimo principas pagrịstas karštųjų krūvininkų reiškiniu ir mikrobangų srovių, tekančių per darinị, kuris susideda iš vienas prieš kitą nuosekliai sujungtų diodų, turinčių skirtingus aktyviųjų sričių plotus, lyginimu. Supaprastintas diodų gamybos technologinis maršrutas ir paprasta puslaidininkinè medžiaga (vienalyčiai legiruoto puslaidininkio plokštelès) leidžia sumažinti tokio mikrobangų diodo gamybos kaštus. Parenkant atitinkamą GaAs padèklą, vienu metu buvo pagaminti dviejų rūšiu mikrobangų diodai: vieni, pasižymintys ominėmis savybėmis, ir kiti du, kurių voltamperinè charakteristika yra netiesinè ir asimetriné, panaši ị Šotkio diodo. Neominiai diodai pasižymejo didesniu voltvatiniu jautriu ir spartesniu atsaku impulsiniam, nanosekundžių skalès, mikrobangų sužadinimui, o ominiai diodai - mažesniais elektroniniais triukšmais ir tiesinèmis voltvatinėmis charakteristikomis, todèl juos galima panaudoti mikrobangu galiai matuoti. 